\title{
WHAT TO DO IN FINANCIAL MARKETS? PREFERENCES AND INCOHERENCES OF FUTURE INVESTORS
}

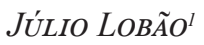

\begin{abstract}
The beliefs and strategies to be mobilized by individuals who are about to start their activity as investors in financial markets is an issue scarcely explored in the field of the sociology of finance. In this paper we present new evidence about the opinions of future investors recurring to a survey administered to 177 master's students. Our results highlight the structural incoherence in the values adopted by future investors and the centrality of these social actors' beliefs in the construction of the prevailing practices in financial markets.
\end{abstract}

KEYWORDS: sociology of finance; structural incoherence; theory of performativity; survey; future investors

\section{INTRODUCTION}

The way social actors imagine the world determines what they think is important, and what they select as the focus of attention among the myriad of facts to which they are constantly exposed. Only after making this selection can thoughts and descriptions begin to be formed (Midgley 2004).

How do future investors assess financial markets? Do they think that it is better to take a defensive strategy and try to avoid losses, or do they think that it is better to accept higher risks in exchange for higher (expected) returns? What kind of discourses and strategies mobilize investors to try to seize investment opportunities, make a profit, and deal with losses? Little is known about these important issues.

1 Júlio Lobão works at University of Porto - School of Economics and Management, Portugal; email: jlobao@fep.up.pt 
This paper examines the beliefs, preferences, and concepts of future investors regarding strategies for adoption in relation to financial markets through responses to a set of 177 questionnaires administered to first-year students of a master's degree in finance at the School of Economics and Management of the University of Porto, Portugal in the period 2015 to 2017. The work developed in this paper follows the research program established by the field of the sociology of finance (MacKenzie 2006; Carruthers and Kim 2011), and thus contributes to this stream of literature.

The growth of internet-based investment and the growth of the financial services industry have been facilitating the activities of non-professional investors over the last two decades (Greenwood and Scharfstein, 2013; Guttman, 2016). In order to understand how financial markets will continue to evolve, one needs to inquire into the trading strategies preferred by future investors. Evidence suggests that a significant proportion of current finance students, given their interest in financial matters, will participate in financial markets at some point in their lives (Arrondel, Debbich and Savignac, 2012; Almenberg e Dreber, 2015). Moreover, the overrepresentation of highly educated individuals in the universe of financial market investors suggests that studying the opinions of university students may be important for understanding the decisions of market participants (Campbell 2006; Calvet, Campbell and Sodini 2007). Inexperienced investors have become an important group among market participants, but they are a subject rarely studied in the field of the sociology of finance (Vollmer, Mennicken and Preda 2009).

The metaphorical concepts related to financial markets that are adopted by future market participants have a significant influence on their performance; they are the matrix of thought, the foundation upon which their mental habits are shaped and those which provide them with the tools with which they organize information about the financial market as a social institution. The importance of the beliefs adopted by the social actors who are about to participate in financial markets can be understood on three levels. First, there are consequences for the agents themselves. For example, if a future investor believes that high returns can be achieved in financial markets, they will be willing to risk greater exposure to those markets. This choice may lead to losses when the investor is faced with situations that run counter to their initial expectations. It should also be noted that, in opposition to the recommendations of standard financial theory, empirical studies show that less experienced investors typically hold undiversified portfolios (Goetzmann and Kumar 2008), trade too much (Barber and Odean 2000), and exhibit gambling behaviors when investing in financial assets (Sjöberg and Engelberg 2009). There is also substantial evidence that the returns obtained by such investors are abnormally low (Barber, Lee, Liu and 
Odean 2009). For all these reasons, understanding the perspectives that future investors have about their own decisions is of paramount importance.

Second, investor beliefs produce consequences for the market itself. Within the framework of social studies in finance, the performativity argument (Callon 1998, 2007; MacKenzie and Millo, 2003; MacKenzie 2006) provides a powerful framework for understanding the central role of the values adopted by social actors - in this case, investors - in terms of the creation of financial markets. Performativity theory claims that the conceptual models adopted by agents contribute to the creation of financial markets.

Finally, it is necessary to identify the values adopted by social actors, because these values, when based on an erroneous interpretation of reality, can have deleterious consequences for social welfare. The role played in the 2007/2008 financial crisis of the (wrong) belief that capital markets necessarily tend towards equilibrium is perhaps one of the best examples of what we have just described (Shefrin and Statman 2012).

This is why it is so important for the social scientist to have some awareness of the formation and stabilization of metaphorical concepts concerning financial markets. In this regard, surveys can provide important insights.

De Bondt (2005) carried out one of the few studies in the field of sociology of finance concerning the beliefs of individual investors. Using investor surveys from six European countries (Belgium, United Kingdom, France, Germany, Italy, and Spain), the author concluded that individuals' "mental frameworks" tend to be shared by the members of the same social group. Their beliefs are correlated with socially relevant variables such as nationality, gender, age, and religion. In addition, their insights about financial markets have predictive power regarding their investment strategies and portfolio choices.

De Bondt's research (2005) focused on wealthy investors: more than half of the sample respondents reported having invested between 100,000 euros and 1 million euros. Our study complements these results by addressing subjects who are new to or about to begin their careers as investors in financial markets.

The remainder of the paper is organized into five sections. We will start by discussing the importance of studying investors' beliefs, and explain how such beliefs can be understood as a reflection of the way social institutions (namely, educational institutions) contribute to the establishment of paradigms. The third section examines the implications of the theory of performativity as a construct that is useful for understanding how markets are created by investors' beliefs, and how investors implement their opinions about the reality they face. The fourth section presents and discusses the details of the survey that underpinned the empirical research. The last section of the paper offers conclusions. 


\section{STUDENTS, NARRATIVES AND EDUCATION SYSTEMS}

Studying the beliefs of students of economics and finance is relevant to sociology. It is important to understand that knowledge in general, and economic and financial knowledge in particular, is increasingly valued for its contribution to economic activity. Such knowledge transmission generally has the significant institutional support of educational systems (Rubinson and Browne 1994). This support is necessary if knowledge is to spread in a given population, and also from generation to generation. Economic theories define patterns of rationality and risk categories and determine the rules that underlie the decisions of social actors. It is now well established that the educational system, through education in the fields of economics and finance, serves to manage identities and to produce subjectivities (Ghoshal and Moran 1996). In fact, an economic education, by contributing to the formation of students' beliefs about the composition of types of agents present in the economy, can trigger strategic responses by individuals. Students tend to adopt behaviors similar to the agents that are assumed to exist in the models they know about. Experimental studies reveal that the teaching of economics and finance, which is often based on the fictional assumption that agents are selfish in nature, is associated with the suppression of cooperative behavior by students (Frank, Gilovich and Regan 1993). As a result, social studies often claim that business schools produce opportunistic agents (Ghoshal 2005).

Callon (1998) argues that the dissemination of economics and finance students by economic institutions is essential in the construction of strong beliefs that allow for the emergence and implantation of arguments and metrological tools. These, in turn, contribute to the triumph of certain forms of framing of economic issues. Social actors tend to become partners and intermediaries, and economic theory is allowed to enter into dialogue with practitioners, shaping their perspectives and actions. In this sense, it is the job of social scientists to study the profession of economists, since it is the latter that produces the knowledge that agents make use of when they undertake so-called "economic functions." Thus, studying students' beliefs about economic reality, and in particular, those of students who are closest to such "economic functions," is one of the most direct ways of accomplishing such a goal.

Studying the values and beliefs of this segment of the population seems to be particularly useful at a time when the relationship between theoretical knowledge and the real world is highly relevant, given the greater proportion of people who have access to university and to the theories and knowledge generated by social scientists. 
Finally, knowing about investors' beliefs is also of importance from the perspective of financial literacy programs. Knowledge of financial concepts is increasingly seen as a way of increasing individuals' participation in financial markets, although data indicate that such participation may depend on other factors such as income and social status (De Bondt 2005). Increasing levels of literacy are needed to help individuals decide in an environment in which financial institutions tend to defend their interests by capitalizing on information asymmetries vis-à-vis their clients (Lépinay 2011). Clearly, the issue of financial literacy lies at the heart of financial decision making. What do individuals really know about financial markets? When a financial problem calls for a decision, there is no clear model of action. Many people use metrological models that do not guarantee good results. The discussion about the most empirically valid courses of action in the financial arena remains a hotly debated issue within the finance literature. Perhaps one of the clearest signs of division in this debate was shown by the awarding of the Nobel Prize in Economic Sciences in 2013 to Eugene Fama and Robert Shiller, two scholars with widely differing views about how financial markets operate.

According to McCloskey (1992), the lives of social actors are closely intertwined in narratives - in stories that are heard and told, and that are reworked to form the story that agents tell themselves. In this sense, social actors live immersed in narratives. Narratives, regardless of their empirical validity, have played a central role in the construction of social knowledge throughout the evolution of the human species (Boyd 2010). The narratives constructed by social actors act as stories that integrate the most important pieces of information to provide the basis for the best decision heuristics. Financial market participants live their lives in metaphors and stories, and today these adaptive elements are the subject of study of social scientists in the most diverse organizational and market contexts (Tuckett 2011; Tarim 2012). Students in the field of financial markets are no exception: they also live surrounded by the rhetoric produced by the education system. The study presented here represents a privileged perspective about the narratives adopted by these economic actors.

\section{STUDENTS, THEORIES AND PERFORMATIVITY}

Studying students' conceptions of economics and about financial markets is important in the context of performativity theory. Performativity is a key concept within sociology of finance (Callon 1998, 2007; Boldyrev and Svetlova 2016). The content of financial economics that is conveyed in universities leads 
to various ideas and formulas being consecrated in capital markets within social actors - in this case, market participants - and adopted as rules of conduct.

The concepts and models of economic science accepted by social actors are more than mere abstractions; they are also constituents of market practices and part of the infrastructure of modern markets. The economy, as argued by Callon (1998, p. 30), "is embedded not in society, but in economics." Economics does not describe a pre-existing external "economy" but rather makes that economy material; economics thus creates the economic system; it gives rise to the phenomenon it describes.

In principle, any belief about price formation, if shared by a sufficiently large number of social actors, can become performative. This assertion is especially important for those investors with greater knowledge of finance, as is the case of the students who operate in this area of knowledge. In fact, one of the most robust results in the literature about financial literacy is that individuals with greater financial knowledge are more likely to participate in financial markets (Yoong, 2011; Arrondel, Debbich and Savignac, 2012; Almenberg and Dreber, 2015).

The approach of performativity theory has been criticized in several areas: for example, the ambiguity of the concept of performativity (Fine, 2003; Mäki, 2013). Some authors consider that the effectiveness of economic science as a performative technique may after all be quite limited since some features of humans (those of a psychological or sociological nature, for example) are undervalued in the process of learning and applying theories (Mäki, 2013). Despite the assumptions of economic theories, market agents are influenced in their decisions by the social norms and values that prevail in the society to which they belong (Santos and Rodrigues, 2009). Therefore, some authors conclude that the performative strength of economic models is very variable, which can lead to significant discrepancies between what is predicted by these models and the outcomes of the decisions that are made by economic agents (Fine, 2003; Aspers, 2007; Santos and Rodrigues, 2009).

The emergence and application of the Black-Scholes formula for option valuation is perhaps the most widely studied example of performativity within the sociology of finance. In two key papers in the field of social studies in finance, Mackenzie and Millo (2003) and MacKenzie (2006) show that, after its introduction into financial markets, the Black-Scholes formula was quickly adopted as a canonical tool, in spite of its unrealistic assumptions. As a consequence, market prices converged to the levels predicted by the model. The model became successful not because its creators had discovered a preexisting price pattern, but because markets, as a result of the widespread use of the formula, made the assumptions of the model more accurate. In other words, 
the success of the model rested on its prescriptive strength, not on its descriptive capability.

According to Ferraro, Pfeffer, and Sutton (2005), theories can become dominant when their related language is widely accepted in a non-critical manner and when their assumptions are accepted and valued as norms, regardless of their empirical validity. New notions and concepts, once introduced into market practices, can define their own realities. When theories create their own beliefs in a self-fulfilling manner, societies, organizations, and leaders can become prisoners of a harmful and unproductive cycle that is almost impossible to break.

The assumption of the performativity argument raises key questions about the domain of ethical responsibility of those agents who use such economic models and contribute to their propagation. On the one hand, the understanding that financial truth is created through a process of performativity means that participants in financial institutions bear (collective) responsibility for the conditions under which they operate, such as price volatility or income inequalities generated by market practices. On the other hand, it is important to understand the dimension of the theory of performativity as a critique of the results of applying standard economic models. The debate over the scope of this critical dimension is still alive in the literature, with a group of authors arguing that the performativity perspective has been too conformist in relation to the false abstractions used by economists (Miller 2002; Mirowski and Nik-Khah 2007, 2008).

In any case, the theory of performativity highlights the eminently historical nature of economic processes. Regularities resulting from the stabilization of certain forms of the organization of market relations remain limited in time and space. Economic science has power because, unlike physics, it can in principle influence the economy through the behavior of social actors. But economic science is also weak in that it is unable to exert this influence at all times and in all economic spaces. There are no natural laws in markets; only temporary and changing laws that can be associated with particular markets in certain historical circumstances. Understanding finance as a performative practice suggests that the processes of knowledge and interpretation are not of secondary importance; they are precisely the way finance materializes. It is not only the case that financial knowledge is socially constructed; it is the very material structures of financial markets - including prices, costs, and capital - that are discursively and historically contingent. Therefore, one of the main implications of the concept of performativity is that it is relevant to study the extent to which concepts, notions, or theories are accepted by social actors. This is precisely what the present study is intended to do. 


\section{SURVEY}

As mentioned before, our study follows the standard survey method. The questionnaires were administered to students of the Markets and Financial Investments (MFI) course that takes place in the first year of the Master of Finance at the School of Economics and Management of the University of Porto (FEP) in Portugal. The questionnaire was written in English - the language in which the MFI course was taught - and was made available in the first MFI class in three consecutive academic years (2015/2016, 2016/2017 and 2017/2018).

The universe of students enrolled in the FIM course is considered to be a good proxy of the group of future investors: first, they are individuals with a clear interest in the financial markets; and second, the Master of Finance at FEP is aimed at students who have completed their bachelor's degree and have not yet started their professional careers.

The choice of finance students as an object of inquiry is not new in the literature. For example, Sjöberg and Engelberg (2009) used a survey with 93 students in this area of knowledge to conclude that individuals expressed a positive attitude towards risk-taking and gambling behaviors.

Our survey contains a total of six statements about which students were asked to give their opinion using a seven-level Likert scale (1: completely disagree in any situation; 2 : strongly disagree in almost all situations; 3 : tend to disagree in most situations 4 : hard to tell; 5 : tend to agree in most situations; 6 : strongly agree in almost all situations; 7 : completely agree in any situation). The six statements presented relate to the best investment strategies to adopt in relation to financial markets. In the analysis of the results, the responses are coded as follows: strong disagreement (-3), moderate disagreement (-2), slight disagreement (-1), neutral response $(0)$, slight agreement $(+1)$, moderate agreement $(+2)$, strong agreement $(+3)$.

\section{Survey results and discussion}

A total of 177 survey responses were collected, while one student did not answer the question regarding educational background. Of the students who provided information, $38(21.6 \%)$ reported having had some experience investing in financial markets, while the vast majority (138 students, accounting for $78.4 \%$ of the total) said they had not. One-hundred-and-sixty-two $(92.0 \%)$ students reported having completed their bachelor's degree in the fields of economics or management (this included courses on economics, management, finance and accounting) and 14 students (8\%) had obtained a degree in another 
domain (including engineering, telecommunications, international relations, international trade, marketing, public administration, philosophy, physics and political science courses).

\section{Overall survey results}

Table 1 presents the overall survey results regarding respondents' opinions about the best investment strategies to be followed in financial markets. It can be observed that most respondents $(52.0 \%)$ disagree that it is possible to systematically obtain better results than those of the market. Only $22.6 \%$ of respondents agree. The general opinion is therefore of disagreement with the first statement, and the higher value of the mean (-0.57) in comparison to the median (-1.0) indicates that there is a minority of individuals who agree in the extreme.

This result contradicts evidence obtained from other studies. For example, Statman (2017) documents from a similar survey of amateur investors that about $62 \%$ of respondents said they believed they could beat the market within a 12 -month period. ${ }^{2}$

If the future investors in our survey considered it impossible to consistently beat the market, we would expect to find answers to the following statements that were consistent with the adoption of passive investment strategies. Indeed, if an investor believes that it is very difficult (or impossible) to systematically achieve better results than the market, one might expect that this investor would try to adopt strategies aimed at achieving market returns (for example, through the purchase of shares of index mutual funds).

However, this is not the case. When answering the second question, a large majority of respondents $(81.4 \%)$ stated that it was important to know what other investors would do before investing. The general opinion here is one of strong agreement $(+1.31)$ and, once again, the mean is higher than the median, thus suggesting the existence of a minority of respondents who agree in the extreme.

2 The concept of beating the market refers to obtaining higher rates of return than the market return, within a given time period, at the same level of risk. 
Table 1 Beliefs about the strategies to adopt when trading in financial markets

\begin{tabular}{|c|c|c|c|c|c|c|c|}
\hline & Mean & Median & Mode & Variance & $\%$ Agree & \% Disagree & Dif. \\
\hline 1. It is possible to beat the market & -0.57 & -1.0 & -1.0 & 1.74 & $22.6 \%$ & $52.0 \%$ & $-29.4 \%$ \\
\hline $\begin{array}{l}\text { 2. When one invests in financial } \\
\text { markets it is important to know } \\
\text { what other investors will do }\end{array}$ & 1.31 & 1.0 & 1.0 & 1.64 & $81.4 \%$ & $10.7 \%$ & $70.7 \%$ \\
\hline $\begin{array}{l}\text { 3. The best strategy for investing in } \\
\text { financial markets is: }\end{array}$ & & & & & & & \\
\hline $\begin{array}{l}\text { 3a... buying the stocks issued by } \\
\text { the best firms }\end{array}$ & 0.03 & 0.0 & 1.0 & 1.21 & $39.6 \%$ & $30.5 \%$ & $9.1 \%$ \\
\hline $\begin{array}{l}3 \text { b. ... buying the stocks issued by } \\
\text { the firms we know best }\end{array}$ & 0.98 & 1.0 & 1.0 & 1.52 & $75.7 \%$ & $13.0 \%$ & $62.7 \%$ \\
\hline $\begin{array}{l}\text { 3c.... investing in a diversified } \\
\text { portfolio }\end{array}$ & 2.26 & 2.0 & 3.0 & 0.94 & $94.9 \%$ & $2.3 \%$ & $92.6 \%$ \\
\hline $\begin{array}{l}\text { 4. If one wants to invest in the long } \\
\text { run, it is better to hold stocks than } \\
\text { treasury bonds (bonds issued by the } \\
\text { governments) }\end{array}$ & -0.27 & 0.0 & -1.0 & 2.21 & $26.6 \%$ & $48.6 \%$ & $-22.0 \%$ \\
\hline
\end{tabular}

Notes: The 177 respondents rated the extent of their agreement or disagreement with each statement. Responses were measured on a seven-point Likert scale, ranging from (-3) to (+3), the extremities of which were labelled "strong disagreement" and "strong agreement," respectively.

It is difficult to reconcile the first two answers. If the market is expected to be difficult to beat, passive investment strategies should be chosen. And if this is the case, it should not be important to know the decisions of other investors in advance. The first two results seem to support the perspective of authors such as Zuckerman (2004) and Tarim (2012) who claim that financial markets, as an area of meaning and practice, are a structurally incoherent terrain due to the different positionality of social actors regarding this institution.

The following statements refer to students' responses about the best investment strategies to pursue. In relation to Statement 3a, it is worth noting that individuals are clearly divided about the desirability of buying stocks issued by the best firms. The level of agreement (39.6\%) and disagreement (30.5\%) are relatively similar. This is the statement concerning which the level of division among respondents was the most profound. As a result, the overall opinion is neutral $(+0.03)$ and very close to the median $(0.0)$.

Again, the responses to the next two statements show traces of inconsistency in the preferences of the respondents. In relation to Statement $3 b$, a large majority of respondents (75.7\%) believe that it makes sense to buy stocks from companies that one knows best; only $13 \%$ of respondents disagree. Thus, the overall level of agreement is high (the mean opinion is +0.98 ) and opinions are essentially symmetrical (median value of +1.0 ). This response indicates that a majority 
of respondents accept the fundamental principle of "value strategies." Value strategies are perhaps the main active strategy, and rest on the assumption that the best firms can be chosen from the range of possible investment alternatives (this practice is commonly referred to as stock picking). ${ }^{3}$

Answers to Statement $3 \mathrm{~b}$ appear to be in opposition to the responses observed with respect to Statement 3c. A very large majority (94.9\%) of respondents agree with the idea expressed in Statement $3 \mathrm{c}$ that a passive investment strategy, obtained through portfolio diversification, is the best alternative. ${ }^{4}$ Only $2.3 \%$ of the responses involved disagreement. The overall level of agreement is very strong (the mean is +2.26 ), and the most frequent opinion is of strong agreement (the mode is +3.0 ), while there are some individuals who very strongly agree (the median is +2.0) and the level of dispersion of responses is the lowest of all the statements under scrutiny (variance of 0.94 ).

The belief among higher-educated future investors that diversification is a beneficial strategy supports the findings of Reinholtz, Fernbach and De Langhe (2016). The authors report that many people incorrectly believe that diversification increases the mean performance of a portfolio. This bias is especially severe in the case of individuals with a high level of financial literacy, such as those covered by our survey. Regardless of the reasons behind the answers in our survey, the widespread acceptance of the perceived benefits of diversification is an extremely important result from the perspective of financial literacy. For example, Statman (2013) shows that diversification strategies remain the best way to protect portfolios from large losses, even in the context of a financial crisis. Nevertheless, the apparent contradiction between the preferences exhibited in the responses to Statements $3 b$ and $3 c$ seem to reinforce the importance of the structural incoherence mentioned above.

Future investors disagree moderately with the last statement $(-0.27$ mean opinion) that investing in stocks is better than investing in long-term treasury bonds. There are some extremely negative opinions (the median is 0.0 ) and the level of divergence of opinions is very high, which is reflected in this statement having the largest variance of the whole set (2.21). It is interesting to note that the general opinion expressed in this statement not only runs counter to

\footnotetext{
3 A value strategy refers to the identification of mispricing among securities that share similar economic and financial characteristics (Lakonishok, Shleifer and Vishny, 1994; Lobão and Azeredo, 2018). Stock picking, also known as selectivity, can be defined as the ability to select securities that are undervalued and will outperform the market over some period of time (Mikhail,Walther and Willis, 2004; Neto, Lobão and Vieira, 2017).

4 Diversification is a risk management strategy that involves mixing a wide variety of basically uncorrelated securities or asset classes with others within a portfolio with the objective of reducing the overall risk of the portfolio.
} 
empirical evidence that shows that, in the long run, stocks are the class of asset that yields higher risk-adjusted returns (Siegel, 2014), but also differs from the results reported by De Bondt (2005) in a similar survey conducted with a group of European investors with large portfolios.

\section{Survey results by trading experience and field of academic degree}

When investigating how beliefs, preferences, and opinions differ for different investor demographic groups, one usually has to introduce financial variables as control variables. However, in the case of our survey the respondents are a fairly homogeneous group - they are all students with an interest in the field of finance. For this reason, we present in Table 2 the comparisons between means computed for two subgroups of respondents. The purpose is to highlight possible differences between the latter.

Trading experience seems to produce some change in investors' beliefs about financial markets. Although there is general disagreement with respect to the first statement in both subgroups (experienced respondents and inexperienced respondents), the percentage of positive (agreement) responses is more pronounced in the subgroup of experienced investors. Only $18 \%$ of inexperienced investors agree with the latter statement, while for the sub-group of investors with trading experience the proportion of individuals who concur reaches $39.5 \%$. The difference is statistically significant at a significance level of $1 \%$. This result is consistent with the assertion presented by Barber and Odean (2001, 2002), among others, that a belief in one's own capacities may be a strong source of motivation for investing in financial markets.

With regard to the second statement, the belief that it is important to know about the performance of other investors is stronger in the case of investors with trading experience $(+1.48$ vs. +1.24$)$, but the difference is not statistically significant.

Opinions about Statements $3 \mathrm{a}$ and $3 \mathrm{c}$ are not significantly different between the two subgroups. As for Statement $3 b$ - the best strategy is to buy stocks issued by firms people know best - the proportion of "agree" responses is higher for the subgroup of inexperienced respondents (78.4\% vs. $65.8 \%)$ and the difference is significant but only at a level of $10 \%$.

A substantial divergence of opinion may be observed again with regard to the last statement: while individuals with no trading experience show a preference for holding long-term bonds (mean opinion of - 0.45 ; percentage of concurring responses of $20.9 \%$ ), respondents who already have traded in financial markets agree with the idea that it is better to hold stocks in the long term (mean opinion 
of $+0.39 ; 47.4 \%$ concurring responses). The difference is statistically significant at a level of $1 \%$. The opinion of experienced respondents is in accordance with the argument presented by Siegel (2014). The author shows that, historically, the stock market has generated abnormally high long-term returns in most countries. This fact, commonly referred to as the "equity risk premium puzzle," is attributed to investors' excessive reluctance to invest their savings into these markets. Our results complement Siegel's (2014) argument, as they indicate that this reluctance to enter the stock market is based on the (historically erroneous) belief that bonds produce superior results in the long term.

Table 2 Beliefs about the right strategies to adopt when trading in financial markets according to trading experience and field of academic degree

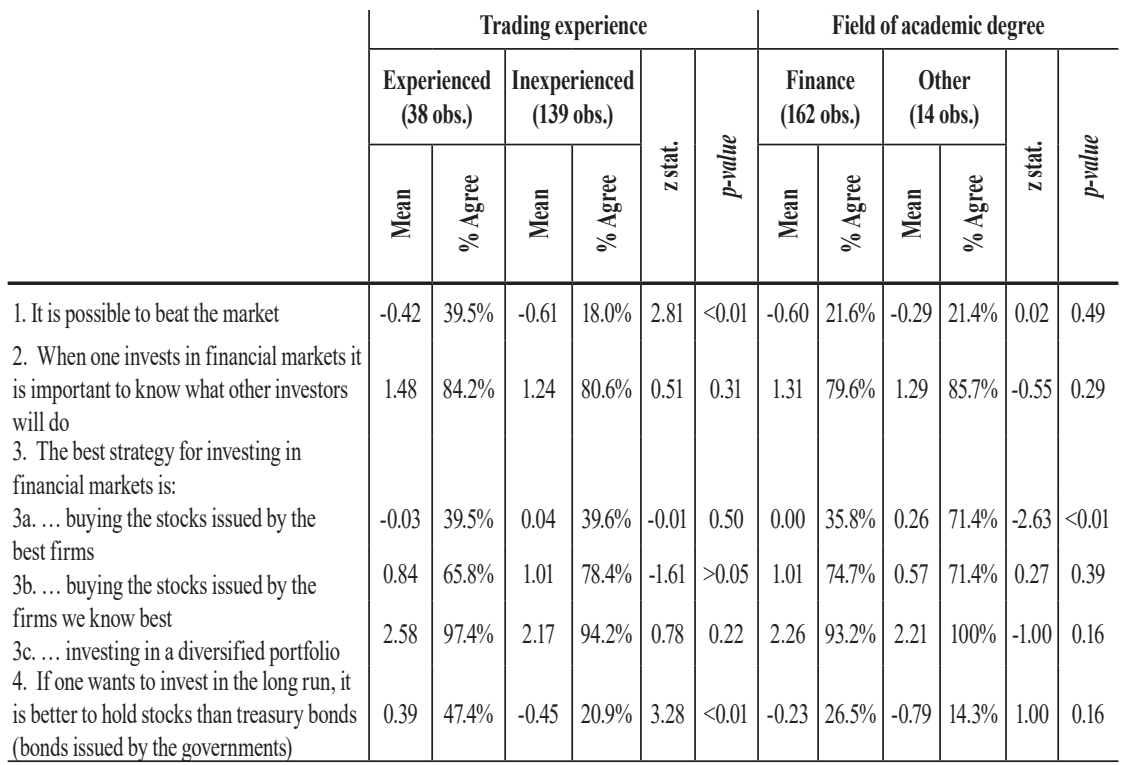

Notes: The 177 respondents rated the extent of their agreement or disagreement with each statement. One of the respondents did not answer the question regarding the field of academic background. The responses were measured on a seven-point Likert scale, ranging from (-3) to (+3), whose extremities are labelled "strong disagreement" and "strong agreement," respectively. The z statistic tests whether the levels of agreement in the two subgroups of respondents are significantly different.

According to performative theory, as mentioned earlier, market participants produce value judgments based on metrological disciplines - that is, based on disciplines that aim to measure some aspect of reality. As has been emphasized by several economic sociologists who agree with the argument of performativity 
(Abolafia 1996; DiMaggio 2002; Pixley 2002; Davis 2006), social actors operate by observing and conforming to the objectives defined by economics and other related scientific disciplines. It was this perspective that led us to break down the results between respondents with an academic background in economics (which includes having completed a course on economics, management, finance, and accounting) and respondents with other areas of expertise.

Results about the impact of the students' field of expertise should be considered with caution given the relatively small number of respondents who reported to having a degree in a field apart from economics. It should be noted, however, that this factor in general does not seem to be of fundamental importance in terms of opinions about

the best strategies to adopt with regard to financial markets. In fact, with the notable exception of Statement 3a, for all the remaining statements the differences observed in the preferences of the two sub-groups was found not to be conventionally statistically significant.

The only significant difference observed in the opinions between the two subgroups of respondents is connected to Statement 3a ("The best strategy for investing in financial markets is to buy stocks issued by the best firms"). The proportion of concurring responses is about double in the group of individuals with no academic background in finance ( $71.4 \%$ vs. $35.8 \%)$, and the difference is found to be highly statistically significant (p-value of less than 0.01 ). This result indicates that learning about pricing mechanisms may be important for helping future investors overcome beliefs that have no empirical support.

\section{CONCLUSION}

As Krippner (2005, p. 173) states, "it is difficult to escape the impression that we live in a world of finance." The extraordinary growth of finance over past decades has been accompanied by remarkable efforts to develop the sociology of economics and the sociology of finance (Smelser and Swedborg 1994; Cetina and Preda 2005).

In this paper, we follow the research program of the sociology of finance and investigate, through the survey method, the beliefs of a group of 177 master's students of the School of Economics and Management at the University of Porto (Portugal). The group is understood to be a good proxy of the class of future investors in financial markets.

The opinions collected in the survey show that future investors do not believe that it is possible to consistently beat the market, and that the best strategy is 
to invest in a diversified portfolio. This result contradicts other preferences expressed in the same survey and by the same individuals; namely, the idea that one should buy the shares of the companies one knows best, and also the notion that it is important to know what other investors intend to do in financial markets. The inconsistency found in the results is highly significant within the framework of social studies in finance. Indeed, the latter seem to confirm the claim that the universe of financial markets, being characterized by high levels of uncertainty and ambiguity, tends to be inhabited by social actors with structurally incoherent positions (Zuckerman 2004; Tarim 2012). Sociology of finance has revealed that current and future market participants tend to develop different beliefs and rituals (Abolafia 1996) that eventually manifest themselves in incoherent market practices (Beunza and Stark 2005).

The empirical evidence presented in our paper is also relevant with respect to financial literacy programs. Our results suggest that trading experience is important in highlighting to market participants the benefits of long-term stock market participation. In this sense, the responses suggest that the potential benefits of financial literacy strategies may not be solely based on more formal learning methods, but may also rest on activities such as virtual market participation and trading simulation practices (Mandel 2006; Harter and Harter, 2010).

Our study also contributes to developing the conjectures underpinning performativity theories in a financial context. In fact, the results show that institutions such as financial markets that may at first sight appear to be nature-like, or purely technical, are in fact culturally constituted and shaped by social relations and by the relative positioning of actors towards these institutions. For example, the results indicate that while respondents in general disagree that investing in stocks leads to better results in the long term, there are significant differences between the beliefs of individuals with and without trading experience. Following Fama (1970), it is plausible to admit that financial prices only reflect the pieces of information that investors believe are most important. However, if a large proportion of investors believe that it is better to adopt passive investment strategies and ignore the information that is available about the market, prices should incorporate that information only slowly and incompletely. Thus, given that the vast majority of the respondents in our study $(94.9 \%)$ believe that portfolio diversification is the best investment strategy, it is expected that these future investors will not contribute to the rapid incorporation of such information into financial prices. Thus, following the reasoning of the theory of performativity, it is possible to understand how diversity in the beliefs of social actors can be translated into a variety of practices and strategies in financial markets. 
One of the questions left open by this study concerns the degree of persistence over time of the results reported here. On the one hand, it has been argued that the relationships that are established between investors and the investment services industry play a key role in the beliefs developed by market practitioners. The investment services industry provides conceptions and metrological tools for analyzing financial markets, helps to create a discourse about these institutions, and forges strong emotional personal relationships (Roscoe, 2015). However, the rapid development of the industry of investment services may also help to change investor beliefs, with consequences that are difficult to predict. On the other hand, in the aftermath of the most significant global financial crisis of the last 80 years, several scholars and political agents have questioned the role that the financial system has played over the last decades. A vast literature on the so-called "financialization of economies" has proliferated over recent years, and has addressed the phenomenon from an essentially critical perspective (Krippner 2005; Lin and Tomaskovic-Devey 2011, 2013). Whether these criticisms will ever be reflected in investors' beliefs is a matter that should be addressed by social scientists in the future.

\section{REFERENCES}

Abolafia, M.Y. (1996) Making Markets: Opportunism and Restraint on Wall Street. Cambridge, MA: Harvard University Press.

Almenberg, J. and Dreber, A. (2015) Gender, Stock Market Participation and Financial Literacy, Economic Letters Vol. 137, pp. 140-142. doi: 10.1016/j. econlet.2015.10.009

Arrondel, L., Debbich, M., and Savignac, F. (2012) Stockholding and Financial Literacy in the French Population, International Journal of Social Sciences and Humanity Studies Vol. 4, pp. 285-294.

Aspers, P. (2007) Theory, Reality, and Performativity in Markets, American Journal of Economics and Sociology Vol. 66, pp. 379-398. doi: 10.1111/j.15367150.2007.00515.x

Barber, B.M. and Odean, T. (2000) Trading Is Hazardous to Your Wealth: The Common Stock Investment Performance of Individual Investors, Journal of Finance Vol. 55, pp. 773-806. doi:10.1111/0022-1082.00226

Barber, B.M. and Odean, T. (2001) Boys will be Boys: Gender, Overconfidence, and Common Stock Investment, Quarterly Journal of Economics Vol. 1, pp. 262-292. doi:10.1162/003355301556400 
Barber, B.M. and Odean, T. (2002) Online Investors: Do the Slow Die First? Review of Financial Studies Vol. 15: pp. 455-487. doi:10.1093/rfs/15.2.455

Barber, B.M., Lee, Y., Liu, Y., and Odean, T. (2009) Just How Much Do Individual Investors Lose by Trading? Review of Financial Studies Vol. 22, pp. 609-632. doi:10.1093/rfs/hhn046

Beunza, D., and Stark, D. (2005) How to recognize opportunities: Heterarchical search in a trading room. In Cetina, K.K., and Preda, A. (Eds.) The Sociology of Financial Markets. Oxford: Oxford University Press, pp. 85-101.

Boldyrev, I., and Svetlova, E. (Eds.) (2016) Enacting Dismal Science: New Perspectives on the Performativity of Economics. London: PalgraveMacmillan.

Boyd, B. (2010) On the Origin of Stories: Evolution, Cognition, and Fiction. Cambridge, MA: Harvard University Press.

Callon, M. (1998) The Embeddedness of Economic Markets in Economics. In Callon, M. (Ed.) The Laws of the Markets, pp. 1-57, Oxford: Blackwell.

Callon, M. (2007) What Does It Mean to Say that Economics is Performative? In MacKenzie, D., Muniesa, F., and Siu, L. (Eds.) Do Economists Make Markets? On the Performativity of Economics. Princeton, NJ: Princeton University Press, pp. 311-357.

Calvet, L., Campbell, J., and Sodini, P. (2007) Down or Out: Assessing the Welfare Costs of Household Investment Mistakes, Journal of Political Economy Vol. 115, pp. 707-747. doi:10.1086/524204

Campbell, J. (2006) Household finance, Journal of Finance Vol. 61, pp. 15531604. doi:10.1111/j.1540-6261.2006.00883.x

Carruthers, B.G. and Kim, J. (2011) The Sociology of Finance, Annual Review of Sociology Vol. 37, pp. 239-259. doi:10.1146/annurev-soc-081309-150129

Cetina, K. K., and Preda, A. (Eds.) (2005) The Sociology of Financial Markets. Oxford: Oxford University Press.

Davis, A. (2006) The Limits of Metrological Performativity: Valuing Equities in the London Stock Exchange, Competition \& Change Vol. 10, pp. 3-21. doi:10.1179/102452906X91984

De Bondt, W. (2005) The Values and Beliefs of European Investors. In Cetina, K.K., and Preda, A. (Eds.) The Sociology of Financial Markets. Oxford: Oxford University Press, pp. 163-186.

DiMaggio, P. (2002) Endogenizing 'animal spirits': Towards a sociology of collective response to uncertainty and risk. In Guillén, M. F., Collins, R., England, P., and Meyer, M. (Eds.) The New Economic Sociology: Developments in an Emerging Field. New York: Russell Sage Foundation, pp. 79-100. 
Fama, E. (1970) Efficient Capital Markets: A Review of Theory and Empirical

Work, Journal of Finance Vol. 25, pp. 383-417. doi:10.2307/2325486

Ferraro, F., Pfeffer, J., and Sutton, R.I. (2005) Economics Language and

Assumptions: How Theories Can Become Self-Fulfilling, Academy of Management Review Vol. 30, pp. 8-24. doi:10.2307/20159091

Fine, B. (2003) Callonistics: A Disentanglement, Economy and Society Vol. 32, pp. 478-484. doi: 10.1080/03085140303128

Frank, R.H., Gilovich, T., and Regan, D.T. (1993) Does Studying Economics Inhibit Cooperation?, Journal of Economic Perspectives Vol. 7, pp. 159-171.

Ghoshal, S. (2005) Bad Management Theories are Destroying Good Management Practices, Academy of Management Learning \& Education Vol. 4, pp. 75-91. doi:10.5465/AMLE.2005.16132558

Ghoshal, S., and Moran, P. (1996) Bad for Practice: A Critique of the Transaction Cost Theory, Academy of Management Review Vol. 21, pp. 13-47. doi: $10.2307 / 258627$

Goetzmann, W., and Kumar, A. (2008) Equity Portfolio Diversification, Review of Finance Vol. 12, pp. 433-463. doi:10.1093/rof/rfn005

Greenwood, R. and Scharfstein, D. (2013) The Growth of Finance, Journal of Economic Perspectives Vol. 27, pp. 3-28. doi: 10.1257/jep.27.2.3

Guttman, R. (2016) Finance-Led Capitalism: Shadow Banking, Re-Regulation, and the Future of Global Markets. Palgrave Macmillan.

Harter, C. and Harter, J. F. R. (2010) Is Financial Literacy Improved by Participating in a Stock Market Game?, Journal of Economic Educators Vol. 10, pp. 21-32.

Krippner, G. (2005) The Financialization of the American Economy, SocioEconomic Review Vol. 3, pp. 173-209. doi:10.1093/SER/mwi008

Lakonishok, J., Shleifer, A., and Vishny, R.W. (1994) Contrarian Investment, Extrapolation, and Risk, Journal of Finance Vol. 49, pp. 1541-1578.

0doi: 10.1111/j.1540-6261.1994.tb04772.x

Lépinay, V. (2011) Codes of Finance: Engineering Derivatives in a Global Bank. Princeton, NJ: Princeton University Press.

Lin, K., and Tomaskovic-Devey, D. (2011) Income Dynamics, Economic Rents, and the Financialization of the U.S. Economy, American Sociological Review Vol. 76, pp. 538-559. doi:10.1177/0003122411414827

Lin, K., and Tomaskovic-Devey, D. (2013) Financialization and U.S. Income Inequality, 1970-2008, American Journal of Sociology Vol. 118, pp. 12841329. doi:10.1086/669499

Lobão, J. and Azeredo, M. (2018) Momentum Meets Value Investing in a Small European Market, Portuguese Economic Journal Vol. 17, pp. 45-58. doi: 10.1007/s10258-017-0135-Z 
MacKenzie, D. (2006) An Engine, Not a Camera: How Financial Models Shape Markets. Cambridge, MA: MIT Press.

MacKenzie, D., and Millo, Y. (2003) Constructing a Market, Performing Theory: The Historical Sociology of a Financial Derivatives Exchange, American Journal of Sociology Vol. 109, pp. 107-145. doi:10.1086/374404

Mäki, U. (2013) Performativity: Saving Austin from Mackenzie, In Karakostas; V. and Dieks, D. (Eds.) Perspectives and Foundational Problems in Philosophy of Science. Dordrecht: Springer, pp. 443-453.

Mandell, L. (2006) Financial literacy: Improving education results of the 2006 national Jump\$tart survey. Washington, DC: Jumpstart Coalition.

McCloskey, D. (1992) The Rhetoric of Finance. In Eatwell, J., Milgate, M., \& Newman, P. (Eds.) The New Palgrave Dictionary of Money and Finance. London: Macmillan Press, pp. 350-352.

Midgley, M. (2004) The Myths We Live By. London/New York: Routledge.

Mikhail, M.B., Walther, B.R., and Willis, R.H. (2004) Do security analysts exhibit persistent differences in stock picking ability? Journal of Financial Economics Vol. 74, pp. 67-91. doi: 10.1016/j.jfineco.2003.11.001

Miller, D. (2002) Turning Callon the Right Way Up, Economy and Society Vol. 31, No. 2, pp. 218-233. doi:10.1080/03085140220123135

Miller, D., and Nik-Khah, E. (2007) Markets Made Flesh: Performativity, and a Problem in Science Studies, Augmented with Consideration of the FCC Auctions. In MacKenzie, D., Muniesa, F., and Siu, L. (Eds.) Do Economists Make Markets? On the Performativity of Economics. Princeton, NJ: Princeton University Press, pp. 190-224.

Neto, N., Lobão, J., and Vieira, E. (2017) Do Portuguese mutual funds display forecasting skills? A study on selectivity and market timing ability, Studies in Economics and Finance Vol. 34, pp. 597-631. doi: 10.1108/SEF09-2015-0233

Pixley, J. (2002) Finance Organizations, Decisions and Emotions, British Journal of Sociology Vol. 53, pp. 41-65. doi:10.1080/ 00071310120109320

Reinholtz, N., Fernbach, P. N., and De Langhe, B. (2016) Do People Understand the Benefit of Diversification?, Working Paper, Social Science Research Network.

Roscoe, P. (2015) 'Elephants can't Gallop': Performativity, Knowledge and Power in the Market for Lay-investing, Journal of Marketing Management Vol. 31, pp. 193-218. doi:10.1080/0267257X.2014.976584

Rubinson, R., and Browne, I. (1994) Education and the Economy. In Smelser, N.J., and Swedborg, R. (Eds.) The Handbook of Economic Sociology. Princeton, NJ: Princeton University Press, pp. 581-599. 
Santos, A.C. and Rodrigues, J. (2009) Economics as Social Engineering? Questioning the Performativity Thesis, Cambridge Journal of Economics Vol. 33, pp. 985-1000. doi: 10.1093/cje/ben058

Shefrin, H., and Statman, M. (2012) Behavioral Finance in the Financial Crisis: Market Efficiency, Minsky, and Keynes. In Blinder, A.S., Lo, A.W., and Solow, R.M. (Eds.) Rethinking the Financial Crisis. New York: Russell Sage Foundation, pp. 99-135.

Siegel, J. (2014) Stocks for the Long Run. New York: McGraw-Hill. Sjöberg,L., andEngelberg,E.(2009)Attitudes toEconomic Risk Taking, Sensation Seeking and Values of Business Students Specializing in Finance, Journal of Behavioral Finance Vol. 10, pp. 33-43. doi:10.1080/15427560902728712

Smelser, N. J., and Swedborg, R. (Eds.) (1994) The Handbook of Economic Sociology. Princeton, NJ: Princeton University Press.

Statman, M. (2013) Is Markowitz Wrong? Investment Lessons from the Financial Crisis, Journal of Portfolio Management Vol. 40, pp. 10-12. doi:10.3905/ jpm.2013.40.1.008

Statman, M. (2017) Finance for Normal People: How Investors and Markets Behave, Oxford: Oxford University Press.

Tarim, E. (2012) Storytelling and Structural Incoherence in Financial Markets, Journal of Interdisciplinary Economics Vol. 24, pp. 115-144. doi:10.1177/0260107913503931

Tuckett, D. (2011) Minding the Markets: An Emotional Finance View of Financial Instability. London: Palgrave-Macmillan.

Vollmer, H., Mennicken, A., and Preda, A. (2009) Tracking the numbers: across accounting and finance, organizations and markets, Accounting, Organizations and Society Vol. 34, pp. 619-637. doi:10.1016/j.aos.2008.06.007

Yoong, J. (2011) Financial Illiteracy and Stock Market Participation: Evidence from the RAND American Life Panel. In Mitchell, O.S. and Lusardi, A. (Eds.) Financial Literacy: Implications for Retirement Security and the Financial Marketplace. Oxford/New York: Oxford University Press, pp. 76-97.

Zuckerman, E.W. (2004) Structural incoherence and stock market activity, American Sociological Review Vol. 69, pp. 405-432. 